\title{
PENINGKATAN KEMAMPUAN MENULIS LAPORAN OBSERVASI MELALUI MODEL PEMBELAJARAN KONTEKSTUAL PADA MAHASISWA D-III SEKRETARI UNIVERSITAS PAMULANG
}

\author{
Nurhayati ${ }^{1}$, Lisa Novia ${ }^{2}$, Annie Rufeidah ${ }^{3}$ \\ Dosen D-III Sekretari Universitas Pamulang \\ dosen01850@unpam.ac.id
}

\begin{abstract}
ABSTRAK
Penelitian yang berjudul "Peningkatan Kemampuan Menulis Laporan Observasi melalui Model Pembelajaran Kontekstual Pada Mahasiswa Prodi D-3 Sekretari Universitas Pamulang" dipilih oleh Penulis karena berasal dari pemikiran bahwa masih banyak mahasiswa yang belum mampu menuliskan laporan observasi dengan baik. Banyak sekali kesalahan-kesalahan dalam menulis laporan observasi, baik dari segi tulisan maupun isi. Hal ini dikarenakan rendahnya pengetahuan mahasiswa dalam menulis laporan. Oleh karena itu upaya yang dilakukan adalah meningkatkan kemampuan menulis laporan observasi mahasiswa yaitu dengan menggunakan model pembelajaran kontekstual. Tujuan dari penelitian ini adalah untuk mengetahui peningkatan kemampuan menulis laporan observasi melalui model pembelajaran kontekstual mahasiswa Prodi D-3 Sekretari Universitas Pamulang. Subjek penelitian ini adalah mahasiswa semester VI regular C kelas 644 D-III Sekretari Universitas Pamulang dengan jumlah total 36 mahasiswa. Metode yang digunakan dalam penelitian ini adalah mix method. Analisis kuantitatif dilakukan secara terus menerus setiap siklus yang terdiri dari empat langkah, yaitu perencanaan (planning), tindakan (action), pengamatan (observing), dan refleksi (reflecting) dengan prosentase kenaikan, sedangkan analisis kualitatif dilakukan dengan cara menganalisis data dari hasil catatan lapangan, cwawancara, dan dokumentasi selama penelitian.
\end{abstract}

Kata kunci : kemampuan menulis, laporan, observasi, pembelajaran kontekstual

\section{ABSTRACT}

The research entitled "Improving the Ability to Write Observation Reports through Contextual Learning Models for Students of the Secretary Diploma at Pamulang University" was chosen by the author because it stems from the idea that there are many students who have not been able to write observation reports properly. There are so many mistakes in writing observation reports, both in terms of writing and content. This is due to the low knowledge of students in writing reports. Therefore, the effort made is to improve the ability to write student observation reports by using a contextual learning model. The purpose of this research was to determine the increase in the ability to write observation reports through the contextual learning model of students of Secretary diploma at Pamulang University. The subject in this research were students of semester VI regular C class 644 Secretary diploma of Pamulang University with a total of 36 students. The method used in this research is the mix method. Quantitative analysis is carried out continuously in each cycle consisting of four steps : planning, action, observing, and reflecting with a percentage increase, while qualitative analysis is carried out by analyzing data from the notes. fieldwork, interview notes, and documentation notes during the study.

Keywords: writing ability, report, observation, contextual learning 
PENDAHULUAN

\section{Latar Belakang Masalah}

Pembelajaran menulis ini sangatlah penting diterapkan bagi mahasiswa. Melalui menulis, mahasiswa akan mampu mampu menuangkan gagasan, ide, dan pikirannya ke dalam bentuk tulisan. Oleh karena itu, kegiatan menulis ini haruslah berulang-ulang diajarkan dan dilatih kepada mahasiswa dengan baik sehingga menimbulkan kebiasaan menulis. Melihat kenyataannya, tidak banyak mahasiswa yang gemar menulis. Di antara penyebabnya ialah karena masih banyak mahasiswa yang belum mampu menulis dengan baik khususnya laporan observasi. Banyak sekali kesalahan-kesalahan dalam menulis laporan observasi, baik dari segi tulisan maupun isi. Hal ini disebabkan karena rendahnya pengetahuan mahasiswa dalam menulis laporan.

Dalam membuat laporan observasi, mahasiswa harus mampu

memperoleh kesimpulan dari hasi pengamatan di lapangan. Untuk menghasilkan mahasiswa yang berkompeten dalam menulis laporan observasi dibutuhkan dosen yang benarbenar memahami dan menguasai setiap kompetensi yang akan diajarkan kepada mahasiswa. Dosen harus mampu menyalurkan pengetahuan dan teknik menulis laporan observasi tersebut kepada mahasiswa, selain itu salah satu upaya yang dilakukan dosen dalam meningkatkan kemampuan menulis laporan observasi mahasiswa ialah dengan menggunakan model pembelajaran kontekstual. Dengan upaya tersebut, diharapkan mahasiswa dapat meningkatkan kemampuan menulis laporan dengan baik.

Model pembelajaran kontekstual merupakan konsep menghubungkan antara pengetahuan yang dimilikinya dengan penerapannya dalam kehidupan mahasiswa sebagai anggota keluarga dan masyarakat. Dengan konsep itu, hasil pembelajaran diharapkan bermakna. Proses pembelajaran berlangsung secara alamiah dalam bentuk kegiatan kerja dan pengalaman, bukan hanya transfer pengetahuan dari dosen kepada mahasiswa saja, sehingga secara kontekstual mahasiswa dapat mendeskripsikan tulisannya dengan lebih konkret. 
Berdasarkan uraian di atas, maka penulis tertarik untuk mengadakan penelitian tentang kemampuan mahasiswa dalam menulis laporan melalui model pembelajaran kontekstual yang berjudul "Peningkatan Kemampuan Menulis Laporan Observasi Melalui Model Pembelajaran Kontekstual pada Mahasiswa Prodi D-3 Sekretari Universitas Pamulang”

\section{Metode Penelitian}

Penelitian ini menggunakan metode mix method, yaitu analisis kuantitatif yang dilakukan secara terus menerus setiap siklus dengan prosentase kenaikan, sedangkan analisis kualitatif dilakukan dengan cara menganalisis data dari hasil catatan lapangan, wawancara, dan dokumentasi selama penelitian.

\section{LANDASAN TEORI}

Pengertian Kemampuan

Menurut pendapat Robbins dan Judge (2014:35), “Kemampuan adalah kapasitas individu saat ini untuk melakukan berbagai tugas dalam sebuah pekerjaan”. Berdasarkan pengertian tersebut, dapat diketahui bahwa yang dimaksud dengan kemampuan adalah adanya kapasitas seseorang dalam melakukan suatu hal/tugas dalam pencapaian hasil pekerjaan.

\section{Pengertian menulis}

Menulis merupakan kegiatan untuk mengungkapkan pikiran, perasaan, dan penilaian tentang apa yang dibaca kemudian disajikan ulang melalui tulisan. Selain itu menulis merupakan kegiatan menuliskan kata-kata menjadi kalimat seperti pendapat Soeharso (2009:7) menyatakan bahwa menulis adalah kegiatan menuliskan kata-kata menjadi kalimat, kemudian menyusun kalimat menjadi paragraf, dan menyusun paragraf menjadi suatu karangan yang utuh.

Pendapat lain juga mengenai proses yang dilakukan dalam menulis. dikemukakan oleh Suparno dan Yunus (2009: 1) menyatakan bahwa menulis merupakan suatu proses kemampuan, pelaksanaan, danhasilnya diperoleh secara bertahap.

\section{Pengertian Laporan}

Menurut Keraf (2020:284), “Laporan adalah suatu cara komunikasi dimana penulis menyampaikan informasi kepada seseorang atau suatu badan karena tanggung jawab yang dibebankan kepadanya." Berdasarkan pengertian tersebut, dapat diketahui bahwa 
laporan adalah salah satu cara yang dilakukan oleh penulis dalam berkomunikasi kepada seseorang atau badan/instansi tentang informasi yang disampaikan penulis sebagai bentuk tanggung jawab terhadap tugasnya.

\section{HASIL DAN PEMBAHASAN}

\section{Deskripsi Data}

Penelitian ini dilakukan di Universitas Pamulang, dalam dua Siklus. Subjek pada pada penelitian ini yaitu mahasiswa prodi D-III Sekretari semester VI sebanyak 36 mahasiswa.

Sebelum melakukan tindakan pada siklus I, dimana peneliti melakukan tes awal terlebih dahulu, yang bertujuan untuk mengetahui data awal tentang kemampuan menulis laporan observasi mahasiswa kelas 06SKRE001. Mahasiswa menulis laporan pada lembar kerja yang telah disediakan dalam bentuk produk yaitu menulis laporan observasi. Setelah itu, laporan dinilai dengan menggunakan instrumen penelitian meliputi aspek-aspek yang akan dinilai sesuai dengan kisi-kisi menulis laporan diskusi.

\section{Hasil Penelitian Tindakan \\ Pelaksanaan Siklus I}

Berdasarkan tes awal yang dilakukan, mahasiswa memiliki kemampuan menulis karangan laporan observasi yang bervariatif, hanya saja nilainya masih di bawah ketuntasan nilai minimal yang sudah ditetapkan. Adapun hasil tes awal yang diperoleh dijelaskan dengan bentuk tabel berikut ini.

Tabel 1 Nilai Tes Awal (Pretes) Mahasiswa Kelas 06SKRE001

\begin{tabular}{|l|c|c|}
\hline $\begin{array}{c}\text { Nama } \\
\text { Mahasis } \\
\text { wa }\end{array}$ & $\begin{array}{c}\text { Jumlah } \\
\text { Nilai }\end{array}$ & $\begin{array}{c}\text { Keteranga } \\
\mathrm{n}\end{array}$ \\
\hline AR & tiga belas & BT \\
\hline AFM & lima belas & BT \\
\hline AKK & dua belas & BT \\
\hline ADK & lima belas & BT \\
\hline AF & empat belas & BT \\
\hline AI & dua belas & BT \\
\hline ADA & lima belas & BT \\
\hline AH & lima belas & BT \\
\hline AWAY & dua belas & BT \\
\hline AC & dua belas & BT \\
\hline DA & tiga belas & BT \\
\hline DIA & sebelas & BT \\
\hline EY & lima belas & BT \\
\hline FD & sepuluh & BT \\
\hline HS & tiga belas & BT \\
\hline
\end{tabular}




\begin{tabular}{|c|c|c|}
\hline HBZ & lima belas & BT \\
\hline IA & lima belas & BT \\
\hline $\mathrm{JL}$ & sebelas & BT \\
\hline LA & tiga belas & BT \\
\hline LSA & sembilan & BT \\
\hline MS & tiga belas & BT \\
\hline NG & sebelas & BT \\
\hline OTAP & sepuluh & BT \\
\hline RMP & sepuluh & BT \\
\hline RRMN & sembilan & BT \\
\hline SHA & sepuluh & BT \\
\hline SJ & sebelas & BT \\
\hline TB & tiga belas & BT \\
\hline UW & sebelas & BT \\
\hline VN & dua belas & BT \\
\hline WF & lima belas & BT \\
\hline WMI & sebelas & BT \\
\hline WDNS & Tiga belas & BT \\
\hline YH & sembilan & BT \\
\hline YL & Tigaa belas & BT \\
\hline ZMA & sebelas & BT \\
\hline Total & $\begin{array}{l}\text { Empat ratus } \\
\text { empat } \\
\text { puluh dua }\end{array}$ & BT \\
\hline
\end{tabular}

(sumber : hasil data penelitian, 2020)

Keterangan :
$\mathrm{T}=$ Tuntas

$\mathrm{BT}=$ Belum Tuntas

Dari table di atas dapat kita lihat bahwa mahasiswa mempunyai kemampuan yang beragam, rata-rata nilai yang diperoleh dari hasil praintervensi (Tes Awal) yaitu 51.16 Sedangkan ketuntasan nilai minimal yakni $\leq 70$. Dapat dilihat dari 36 mahasiswa, tidak ada mahasiswa yang dapat memenuhi ketuntasan nilai. Pada evaluasi tes awal yang telah dilakukan memiliki banyak kekurangan dari hasil mahasiswa kelas 06SKRE001 perlu ditingkatkan lagi kemampuan mahasiswa dalam menulis lapaoran agar menjadi lebih baik. Adapun Intervensi yang dimaksud adalah intervensi siklus I dengan 2 kali pertemuan.

Adapun kategori penilaian dapat dilihat pada tabel di bawah ini:

Tabel 2 Nilai Siklus 1 (Postes) Mahasiswa Kelas 06SKRE001

\begin{tabular}{|l|l|c|}
\hline $\begin{array}{c}\text { Nama } \\
\text { Mahasis } \\
\text { wa }\end{array}$ & $\begin{array}{c}\text { Jumlah } \\
\text { Nilai }\end{array}$ & $\begin{array}{c}\text { Keteranga } \\
\mathrm{n}\end{array}$ \\
\hline AR & enam belas & BT \\
\hline AFM & enam belas & BT \\
\hline AKK & enam belas & BT \\
\hline ADK & enam belas & BT \\
\hline AF & enam belas & BT \\
\hline AI & enpat belas & BT \\
\hline
\end{tabular}

Jurnal Sekretari | Vol. 8 No. 2 | Juni 2021

Page | 113 


\begin{tabular}{|c|c|c|}
\hline $\mathrm{ADA}$ & enpat belas & BT \\
\hline $\mathrm{AH}$ & enpat belas & BT \\
\hline AWAY & enpat belas & BT \\
\hline $\mathrm{AC}$ & enpat belas & BT \\
\hline DA & tujuh belas & $\mathrm{T}$ \\
\hline DIA & tujuh belas & $\mathrm{T}$ \\
\hline EY & tujuh belas & $\mathrm{T}$ \\
\hline FD & tujuh belas & $\mathrm{T}$ \\
\hline HS & tujuh belas & $\mathrm{T}$ \\
\hline HBZ & $\begin{array}{c}\text { delapan } \\
\text { belas }\end{array}$ & $\mathrm{T}$ \\
\hline IA & $\begin{array}{c}\text { delapan } \\
\text { belas }\end{array}$ & $\mathrm{T}$ \\
\hline $\mathrm{JL}$ & $\begin{array}{c}\text { delapan } \\
\text { belas }\end{array}$ & $\mathrm{T}$ \\
\hline LA & $\begin{array}{c}\text { delapan } \\
\text { belas }\end{array}$ & $\mathrm{T}$ \\
\hline LSA & $\begin{array}{c}\text { delapan } \\
\text { belas }\end{array}$ & $\mathrm{T}$ \\
\hline MS & enam belas & BT \\
\hline $\mathrm{NG}$ & enam belas & BT \\
\hline OTAP & enam belas & $\mathrm{BT}$ \\
\hline RMP & enam belas & BT \\
\hline RRMN & enam belas & BT \\
\hline SHA & enpat belas & BT \\
\hline SJ & enpat belas & BT \\
\hline TB & enpat belas & BT \\
\hline
\end{tabular}

\begin{tabular}{|l|c|c|}
\hline UW & enpat belas & BT \\
\hline VN & enpat belas & BT \\
\hline WMI & $\begin{array}{c}\text { delapan } \\
\text { belas } \\
\text { belas }\end{array}$ & $\mathrm{T}$ \\
\hline WDNS & $\begin{array}{c}\text { delapan } \\
\text { belas }\end{array}$ & $\mathrm{T}$ \\
\hline YH & $\begin{array}{c}\text { delapan } \\
\text { belas }\end{array}$ & $\mathrm{T}$ \\
\hline YL & $\begin{array}{c}\text { delapan } \\
\text { belas }\end{array}$ & $\mathrm{T}$ \\
\hline ZMA & $\begin{array}{c}\text { delapan } \\
\text { belas } \\
\text { Total }\end{array}$ & $\begin{array}{c}\text { Lima ratus } \\
\text { delapan } \\
\text { puluh tiga }\end{array}$ \\
\hline
\end{tabular}

(sumber : hasil data penelitian, 2020)

Berdasarkan tabel 4.2 di atas, dapat disimpulkan bahwa dari 36 mahasiswa kelas 06SKRE001 hanya ada 16 mahasiswa yang telah berhasil sesuai nilai ketuntasan minimum, yaitu 70. Pencapaian tersebut menandakan bahwa adanya peningkatan keterampilan menulis kemampuan menulis laporan observasi melalui model pembelajaran kontekstual mahasiswa kelas kelas 06SKRE001. Namun, skor perolehan rata-rata keterampilan menulis laporanternyata masih belum mencapai nilai ketuntasan minimum secara keseluruhan dan 
rata-rata yang diperoleh pun masih 67.48 Sedangkan, Nilai ketuntasan minimum secara keseluruhan keterampilan menulis adalah $\leq 70$.

\section{Pelaksanaan Siklus II}

Setelah mahasiswa menulis laporan observasi berdasarkan hasil yang telah didiskusikan, maka peneliti dan kolabor menilai hasil laporan dengan menggunakan instrumen penilaian yang sama dengan instrumen penilaian pada siklus I.Hasil penilaian laporan observasi pada siklus II telah mengalami beberapa perubahan. Semua kelompok mampu menuliskan laporan observasi dengan baik.

Tabel 3 Nilai Siklus 2 (Postes) Mahasiswa Kelas O6SKRE001

\begin{tabular}{|l|c|c|}
\hline $\begin{array}{c}\text { Nama } \\
\text { Mahasis } \\
\text { wa }\end{array}$ & $\begin{array}{c}\text { Jumlah } \\
\text { Nilai }\end{array}$ & $\begin{array}{c}\text { Keteranga } \\
\mathrm{n}\end{array}$ \\
\hline AR & $\begin{array}{c}\text { sembilan } \\
\text { belas }\end{array}$ & $\mathrm{T}$ \\
\hline AFM & $\begin{array}{c}\text { sembilan } \\
\text { belas }\end{array}$ & $\mathrm{T}$ \\
\hline AKK & $\begin{array}{c}\text { sembilan } \\
\text { belas }\end{array}$ & $\mathrm{T}$ \\
\hline ADK & $\begin{array}{c}\text { sembilan } \\
\text { belas }\end{array}$ & $\mathrm{T}$ \\
\hline AF & $\begin{array}{c}\text { sembilan } \\
\text { belas }\end{array}$ & $\mathrm{T}$ \\
\hline
\end{tabular}

\begin{tabular}{|c|c|c|}
\hline AI & dua puluh & $\mathrm{T}$ \\
\hline $\mathrm{ADA}$ & dua puluh & $\mathrm{T}$ \\
\hline $\mathrm{AH}$ & dua puluh & $\mathrm{T}$ \\
\hline AWAY & dua puluh & $\mathrm{T}$ \\
\hline $\mathrm{AC}$ & duapuluh & $\mathrm{T}$ \\
\hline DA & $\begin{array}{l}\text { duapuluh } \\
\text { satu }\end{array}$ & $\mathrm{T}$ \\
\hline DIA & $\begin{array}{l}\text { duapuluh } \\
\text { satu }\end{array}$ & $\mathrm{T}$ \\
\hline EY & $\begin{array}{l}\text { duapuluh } \\
\text { satu }\end{array}$ & $\mathrm{T}$ \\
\hline FD & $\begin{array}{l}\text { duapuluh } \\
\text { satu }\end{array}$ & $\mathrm{T}$ \\
\hline HS & $\begin{array}{l}\text { duapuluh } \\
\text { satu }\end{array}$ & $\mathrm{T}$ \\
\hline HBZ & $\begin{array}{l}\text { duapuluh } \\
\text { dua }\end{array}$ & $\mathrm{T}$ \\
\hline IA & $\begin{array}{l}\text { duapuluh } \\
\text { dua }\end{array}$ & $\mathrm{T}$ \\
\hline $\mathrm{JL}$ & $\begin{array}{l}\text { dua puluh } \\
\text { dua }\end{array}$ & $\mathrm{T}$ \\
\hline LA & $\begin{array}{c}\text { dua puluh } \\
\text { dua }\end{array}$ & $\mathrm{T}$ \\
\hline LSA & $\begin{array}{l}\text { dua puluh } \\
\text { dua }\end{array}$ & $\mathrm{T}$ \\
\hline MS & $\begin{array}{c}\text { delapan } \\
\text { belas }\end{array}$ & $\mathrm{T}$ \\
\hline $\mathrm{NG}$ & $\begin{array}{c}\text { delapan } \\
\text { belas }\end{array}$ & $\mathrm{T}$ \\
\hline OTAP & delapan & $\mathrm{T}$ \\
\hline
\end{tabular}




\begin{tabular}{|c|c|c|}
\hline & belas & \\
\hline RMP & $\begin{array}{c}\text { delapan } \\
\text { belas }\end{array}$ & $\mathrm{T}$ \\
\hline RRMN & $\begin{array}{c}\text { delapan } \\
\text { belas }\end{array}$ & $\mathrm{T}$ \\
\hline SHA & tujuh belas & $\mathrm{T}$ \\
\hline SJ & tujuh belas & $\mathrm{T}$ \\
\hline TB & tujuh belas & $\mathrm{T}$ \\
\hline UW & tujuh belas & $\mathrm{T}$ \\
\hline $\mathrm{VN}$ & tujuh belas & $\mathrm{T}$ \\
\hline WF & $\begin{array}{l}\text { duapuluh } \\
\text { satu }\end{array}$ & $\mathrm{T}$ \\
\hline WMI & $\begin{array}{l}\text { duapuluh } \\
\text { satu }\end{array}$ & $\mathrm{T}$ \\
\hline WDNS & $\begin{array}{l}\text { duapuluh } \\
\text { satu }\end{array}$ & $\mathrm{T}$ \\
\hline YH & $\begin{array}{l}\text { duapuluh } \\
\text { satu }\end{array}$ & $\mathrm{T}$ \\
\hline YL & $\begin{array}{l}\text { duapuluh } \\
\text { satu }\end{array}$ & $\mathrm{T}$ \\
\hline ZMA & $\begin{array}{l}\text { duapuluh } \\
\text { satu }\end{array}$ & $\mathrm{T}$ \\
\hline Total & $\begin{array}{l}\text { tujuh ratus } \\
\text { sebelas }\end{array}$ & $\mathrm{T}$ \\
\hline
\end{tabular}

(sumber : hasil data penelitian, 2020

Berdasarkan perbandingan skor kemampuan menulis laporan observasi yang ditampilkan pada tabel di atas, maka kesimpulannya bahwa rata-rata sangat variatif yang diperoleh dari hasil Siklus II yakni 82.29 sesuai dengan nilai ketuntasan minimum yakni $\leq 70$. Dengan demikian, penelitian dianggap selesai.

\section{Pembahasan Hasil dan penelitian Tindakan}

Dari pengujian yang dilakukan oleh peneliti ditemukan beberapa hal penting tentang penggunaan model pembelajaran kontekstual dalam meningkatkan keterampilan menulis laporan mahasiswa kelas 06SKRE001, yaitu kemampuan menulis laporan dapat meningkat jika dosen menggunakan model pembelajaran yang tepat.

Setelah melakukan refleksi prapenelitian, disusunlah rencana tindakan yang akan dilakukan pada siklus I dengan menggunakan model pembelajaran kontekstual dalam meningkatkan keterampilan menulis laporan mahasiswa kelas 06SKRE001. Pada siklus I ini, hanya 11 (sebelas) mahasiswa yang telah berhasil sesuai dengan nilai ketuntasan minimum $\leq 70$. Setelah melakukan refleksi berdasarkan penelitian siklus I, maka melakukan rencana tindakan pada siklus II yang sama dengan tindakan pada siklus I yaitu 
menggunakan model pembelajaran kontekstual. Dalam siklus II, data yang diperoleh bahwa semua mahasiswa mengalami peningkatan sesuai nilai ketuntasan minimum, yaitu mencapai nilai yang baik 82.29. Dari hasil analisis data siklus I sampai siklus II adanya peningkatan sebesar 14.81. Dari hasil analisis data praintervensi ke siklus I adanya peningkatan sebesar 16.32 .

\section{KESIMPULAN DAN SARAN}

\section{Kesimpulan}

Berdasarkan hasil pembahasan

Di atas dapat menyimpulkan bahwa:

a. Kemampuan menulis laporan diskusi dapat ditingkatkan dengan pembelajaran melalui model pembelajaran kontektual.

b. Kemampuan menulis laporan mahasiswa mengalami peningkatan yang tinggi dengan

Berikut tabel tingkat pencapaian pembelajaran yang diterapkan seperti model peningkatan dalam penelitian ini! kontektual.

c. Kebermaknaan pembelajaran bahasa Indonesia dapat ditingkatkan melalui model pembelajaran kontekstual yang akhirnya

Tabel 4 Nilai Akhir Peningkatan Keterampilan Menulis Laporan Mahasiswa Kelas 06SKRE001 mahasiswa dapat menulis laporan diskusi yang diharapkan.

\begin{tabular}{|c|c|c|c|}
\hline No & Penelitian & $\begin{array}{c}\text { Hasil } \\
\text { Penilaian }\end{array}$ & $\begin{array}{c}\text { Selisih } \\
\text { Peningkat } \\
\text { an }\end{array}$ \\
\hline 1. & $\begin{array}{l}\text { Tes Awal } \\
\text { (Pretest) }\end{array}$ & 51.16 & $\mathbf{0}$ \\
\hline 2. & $\begin{array}{l}\text { Tes Akhir } \\
1 \text { (Post test } \\
\text { 1) }\end{array}$ & 67.48 & 16.32 \\
\hline 3. & $\begin{array}{l}\text { Tes Akhir } \\
2 \text { (Post test } \\
\text { 2) }\end{array}$ & 82.29 & 14.81 \\
\hline
\end{tabular}

\section{SARAN}

Berdasarkan kesimpulan di atas, Saran yang ingin penulis memberikan kepada Dosen, yaitu :

a. Dosen harus mampu menerapkan model pembelajaran kontekstual sehingga kemampuan mahasiswa dalam menulis laporan observasi dapat meningkat.

b. Dosen sebaiknya melakukan penelitian tindakan guna mengatasi 


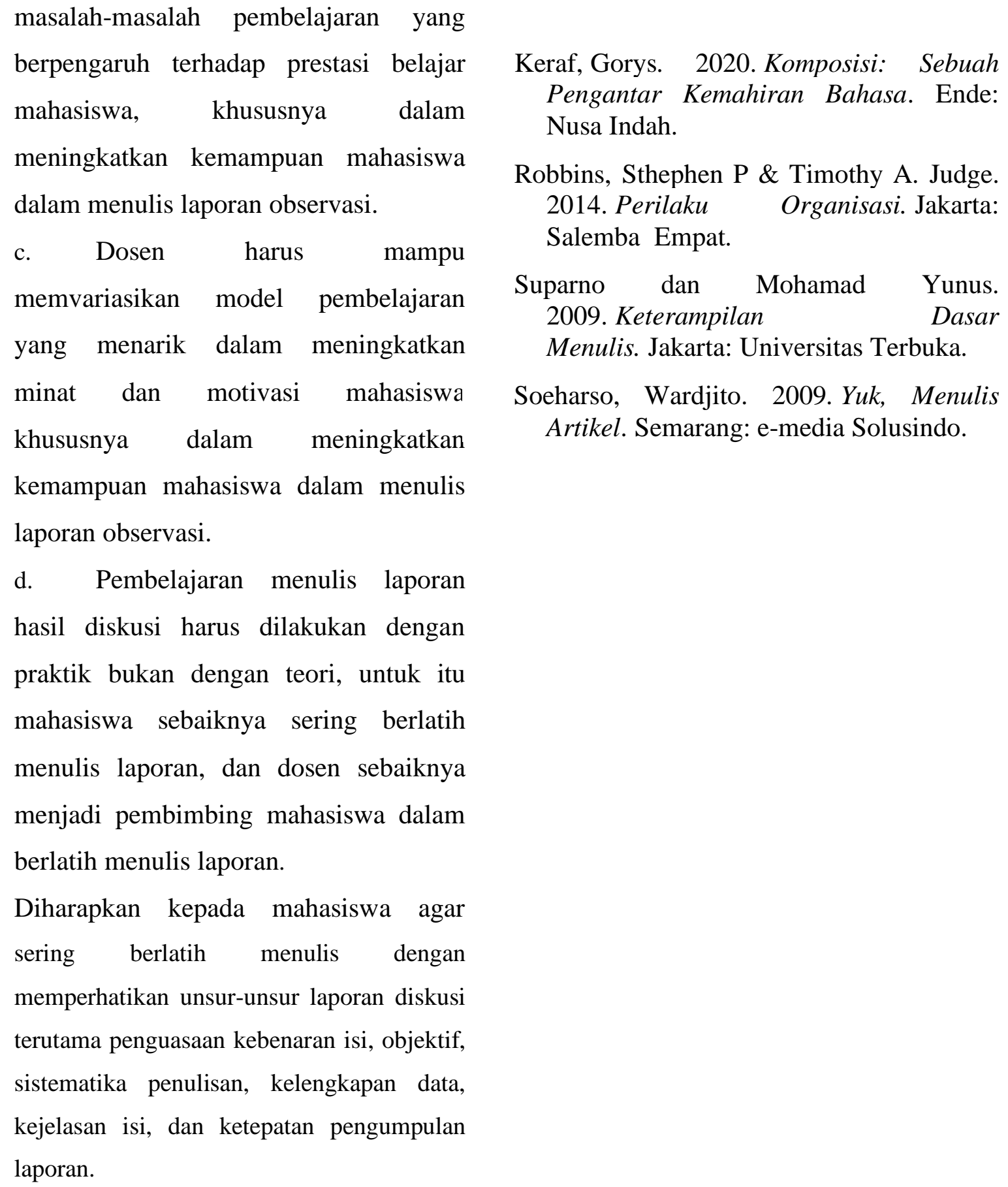

Diharapkan kepada mahasiswa agar sering berlatih menulis dengan memperhatikan unsur-unsur laporan diskusi terutama penguasaan kebenaran isi, objektif, sistematika penulisan, kelengkapan data, kejelasan isi, dan ketepatan pengumpulan laporan.

Keraf, Gorys. 2020. Komposisi: Sebuah Pengantar Kemahiran Bahasa. Ende: Nusa Indah.

Robbins, Sthephen P \& Timothy A. Judge. 2014. Perilaku Organisasi. Jakarta: Salemba Empat.

Suparno dan Mohamad Yunus. 2009. Keterampilan Dasar Menulis. Jakarta: Universitas Terbuka.

Soeharso, Wardjito. 2009. Yuk, Menulis Artikel. Semarang: e-media Solusindo.

\section{DAFTAR PUSTAKA}

